\title{
Cytology of Rutaceae and Simarubaceae
}

\author{
Sharda Desai \\ Botany Department, Gujarat University, \\ Ahmedabad, India
}

Received July 11, 1959

The earliest mention of the cytology of the Rutaceae appeared in 1912, in a paper by Osawa who counted 8 chromosomes instead of 9 in Citrus $s p$. On the Simarubaceae, cytological work only on three genera, Ailanthus, Quassia and Picrasma is recorded. Extensive cytological work has been done on the genus Citrus, in the Rutaceae. The family Simarubaceae consists of 30 genera and about 200 species, the distribution of most of them is in the warmer parts of the world. The Rutaceae is rich in species. The study recorded here concerns the cytology of 10 species in 8 genera of the Rutaceae and 2 species in 2 genera of the Simarubaceae. The following description includes also geographical distribution of Xanthoxylum.

\section{Materials and methods}

Iron acetocarmine squash technique was the most satisfactory one for staining chromosomes. Flower buds were collected from plants growing in their natural condition and were fixed in 3 parts of absolute alcohol: 1 part glacial acetic acid and the freshly fixed material was placed immediately under a vacuum pump. Use of a trace of ferric acetate in the fixative was helpful in some cases. A small portion of the anther or the ovule was dis. sected out and heated to boiling in acetocarmine and then squashed when still hot. It was found that inverting the prepared slide over vapours of con. $\mathrm{HNO}_{3}$ gave better differentiation of the chromosomes in some cases.

Microphotographs were taken from freshly squashed preparations on Ilford Rapid Process Panchromatic plates. The drawings were made with a Zeiss camera lucida.

A list of the plants of this investigation is given below indicating the localities from which they were obtained (Table 1).

As most of my material was obtained from the various botanic gardens in England except Quassia amara which was obtained from Bombay, India, it has not been possible to discover where each species was originally collected.

\section{Observations}

Choisya ternata. It is an ornamental plant with scented flowers. The chromosome count for Choisya ternata was obtained as $\mathrm{n}=27$ (Fig. 1). This 
Table 1

\begin{tabular}{|c|c|c|}
\hline Genus & Classification & Locality \\
\hline \multicolumn{3}{|c|}{ RUTACEAE } \\
\hline Xanthoxylum americanum & $\begin{array}{l}\text { Tribe Xanthoxyleae } \\
\text { Subfamily Rutoideae }\end{array}$ & $\begin{array}{l}\text { Royal Botanic Gardens, } \\
\text { Kew }\end{array}$ \\
\hline Xanthoxylum bungeii & " " & $" \quad "$ \\
\hline Skimmia formanii & $\begin{array}{l}\text { Tribe Toddalieae } \\
\text { Subfamily Toddalioideae }\end{array}$ & Chelsea Physic Gardens \\
\hline Correa backhousiana & $\begin{array}{l}\text { Tribe Boroneae } \\
\text { Subfamily Rutoidae }\end{array}$ & $"$ \\
\hline Ptelea trifoliata & $\begin{array}{l}\text { Tribe Toddalieae } \\
\text { Subfamily Toddalioideae }\end{array}$ & $"$ \\
\hline Evodia danielli & $\begin{array}{l}\text { Tribe Xanthoxyleae } \\
\text { Subfamily Rutoideae }\end{array}$ & $\begin{array}{l}\text { Royal Botanic Gardens, } \\
\text { Kew }\end{array}$ \\
\hline Evodia glocii & " " & " " \\
\hline Phellodendron sachalinense & $\begin{array}{l}\text { Tribe Toddalieae } \\
\text { Subfamily Toddalioideae }\end{array}$ & $\begin{array}{l}\text { Royal Botanic Gardens, } \\
\text { Kew }\end{array}$ \\
\hline Dictamnus albus & $\begin{array}{l}\text { Tribe Rutaceae } \\
\text { Subfamily Rutoideae }\end{array}$ & \multirow[t]{2}{*}{ Chelsea Physic Gardens } \\
\hline & SIMARUBACEAE & \\
\hline Ailanthus altissima & $\begin{array}{l}\text { Tribe Picrasmeae } \\
\text { Subfamily Simaruboideae }\end{array}$ & $\begin{array}{l}\text { Royal Botanic Gardens, } \\
\text { Kew }\end{array}$ \\
\hline Quassia amara & $\begin{array}{l}\text { Tribe Simarubaeae } \\
\text { Subfamily Simaruboideae }\end{array}$ & Bombay, India \\
\hline
\end{tabular}

species shows slightly irregular meiosis, the irregularities being manifested by a few lagging chromosomes at first metaphase. At second anaphase and second metaphase, the twenty-seven chromosomes are spherical (Fig. 2). No previous cytological work on Choisya is recorded.

Correa backhousiana. Pollen mother cells of this species show a regular meiosis and normal tetrad production. At first metaphase 16 bivalents are counted (Fig. 3), in agreement with the counts of three other species of Correa found by Smith. White (1954b). The chromosome number $n=16$ is recorded here for the first time.

Skimmia formanii. This species is a hybrid of $S$. japonica $\times S$. reevesiana. The chromosomes number for this species is determined as $n=16$ (Fig. 4, 5). No cytological work on Skimmia is recorded so far. The pollen grains show considerable variability as regards their shape and size in this species.

Ptelea trifoliata. Original chromosome number for this species was found to be twenty one (Fig. 6) and is the first recorded count for the genus. Meiotic irregularities in the pollen mother cells were observed. Figs. 7, 8, 10 show the formation of univalents and trivalents at metaphase I. Certain round extranuclear bodies which occur regularly were observed at first and second telophase (Fig. 9). They stained to the same extend as the nucleoli with acetocarmine. Their exact function and nature is not known. They 
are not found in the pollen grains. They may probably be bodies extruded from telophase nuclei.

An irregular wall formation occurs in Ptelea which gives rise to one binucleate and two uninucleate spores. The occurrence of polyspory may be as a result of occurrence of lagging chromosomes which organise into micronuclei. The pollen grains arising in this way are non-functional. The plant may be a hybrid and is characterised by a high degree of sterility.
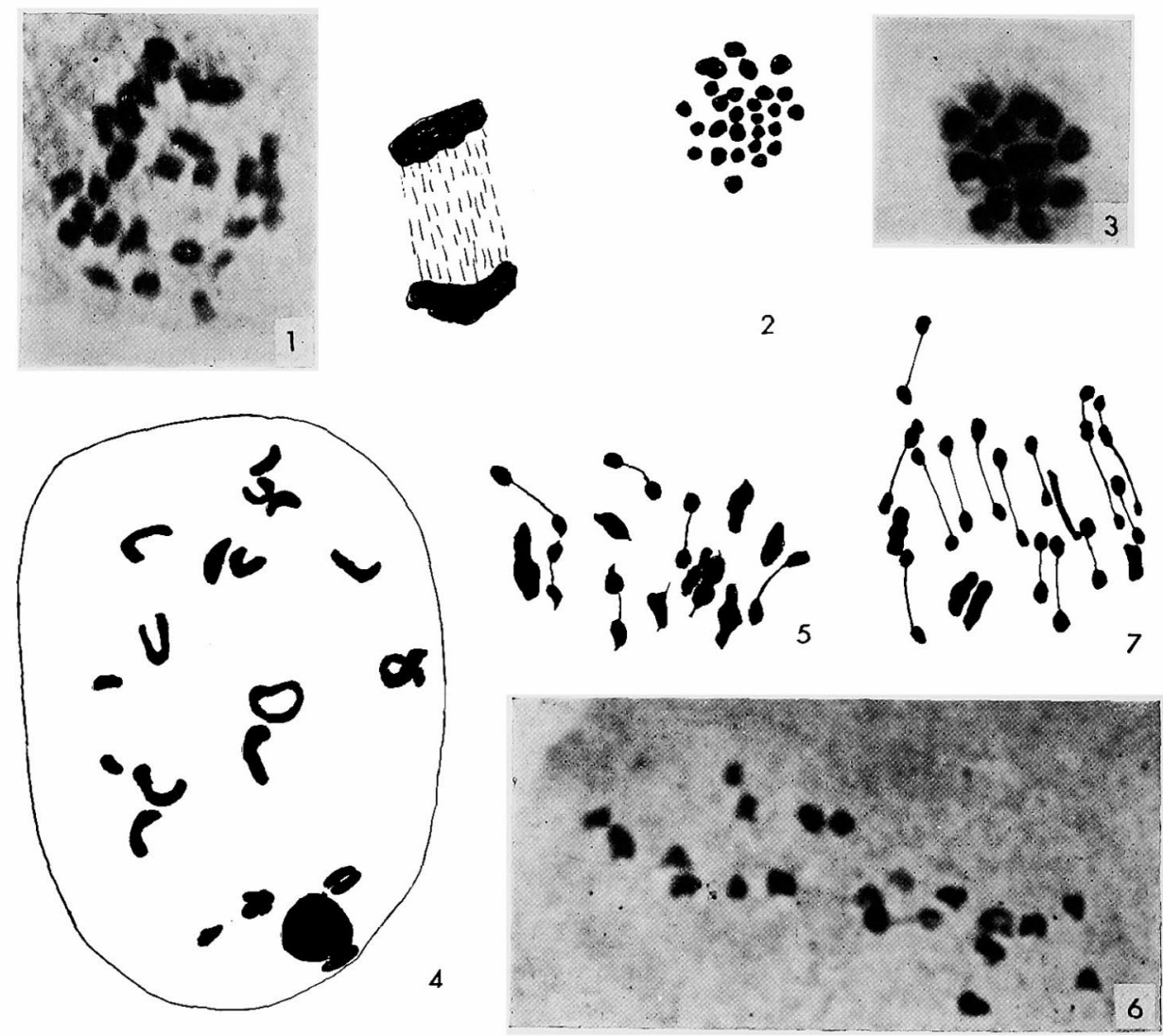

Figs. 1-7. 1, Choisya ternata. First meiotic metaphase. Pollen mother cell. $\mathrm{n}=27 . \times$ 2280. 2, Choisya ternata. Second anaphase. Pollen mother cell, one group showing, $\mathrm{n}=$ 27. $\times 1520.3$, Correa backhousiana. First meiotic metaphase. Pollen mother cell. $\mathrm{n}=16$. $\times 2660$. 4, Skimmia formanii. Diakinesis showing paired chromosomes. $\mathrm{n}=16 . \times 2260$. 5, Skimma formanii. Pollen mother cell. Bivalents showing $\mathrm{n}=16$. $\times 1520$. 6, Ptelea trifoliata. First anaphase. Pollen mother cell showing $n=21$. The other half of the mother cell is not shown in the figure. $\times 1900$. 7, Ptelea trifoliata. First meiotic meta. phase showing associations of 18 bivalents and 3 trivalents. $\times 1520$.

Phellodendron sachalinense. The chromosome number in the pollen mother cells of this plant is found to be forty (Fig. 13) and is the first recorded count for the genus. Pollen mother cells show regular meiosis. The species appears to be fully pollen fertile.

Dictamnus albus var. caucasus. This species shows $\mathrm{n}=36$ (Fig. 11). 
During meiosis irregularities in the form of laggards at first anaphase were observed and frequently chromosome bridges also (Figs. 12). This is in agreement with Bowden's (1945) record of $\mathrm{n}=36$ for Dictamnus albus.

\section{Evodia. The chromosome number for Evodia} daniellii was found as $n=40$ (Fig. 14), this count differing from that of Bowden (1945) who gives $n=36$ for material grown on Blandy Experimental Farm, University of Virginia. It is interesting to note the apparent existence of aneuploidy within the genus Evodia.

Evodia glocii. Evodia glocii has $\mathrm{n}=36$ (Figs. 15) and is the first recorded count for the species. Univalents were observed at diakinesis and at metaphase I. Trivalents also occur in this plant (Fig. 17). Widespread degeneration of pollen grains takes place in this species.

Xanthoxylum. The mitotic chromosome number for Xanthoxylum
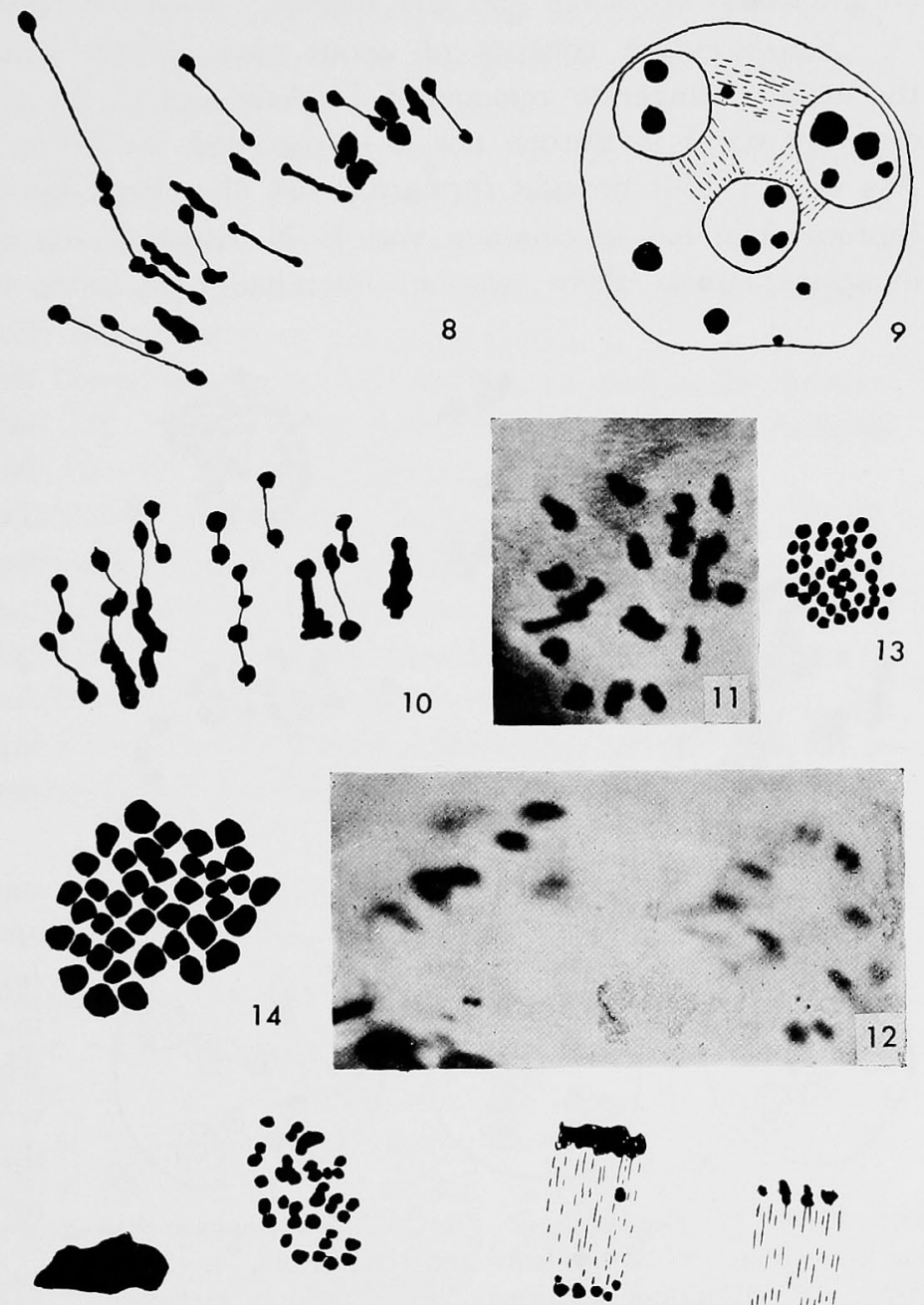

15

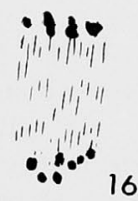

Figs. 8-16. 8, Ptelea trifoliata. First meiotic metaphase showing 1 univalent, 18 bivalents and 2 trivalents. $\times 2280.9$, Ptelea trifoliata. Second meiotic telophase showing extra-nuclear round bodies. $\times 1900$. 10, Ptelea trifoliata. First meiotic metaphase showing formation of multivalents. $\times 2660.11$, Dictamnus albus. Second anaphase. Pollen mother cell showing $n=36$. Other half of PMC is not shown in the figure. $\times 2660.12$, Dictamnus albus. Second anaphase showing chromosome bridge. $\times 1520$. 13, Phellodendron sachalinense. First meiotic metaphase. Pollen mother cell. $\mathrm{n}=40 . \times 1900.14$, Evodia daniellii. First meiotic metaphase. Pollen mother cell. $\mathrm{n}=40 . \times 2660.15$, Evodia glocii. Second anaphase, one group showing $\mathrm{n}=36 . \times 2280.16$, Ailanthus altissima. Second anaphase showing a laggard. $\times 760$. 
americanum is $2 \mathrm{n}=136$. Walker (1942) records $2 \mathrm{n}=68$ for the same species obtained from E. N. America. Xanthoxylum bungeii has $2 \mathrm{n}=32$. The chromosomes are small and rod shaped. Both the species are apomictic.

Xanthoxylum consists of about nine species which are distributed in the mainly temperate regions of E. Asia and E. N. America. This genus does not occur in Europe nor is it recorded in Africa or South America. Asa Gray (1858) brought forward a list of a large number of genera which Eastern Asia has in common with E. N. America. It is quite possible, that in ancient times there was an interchange of forms between E. Asia and
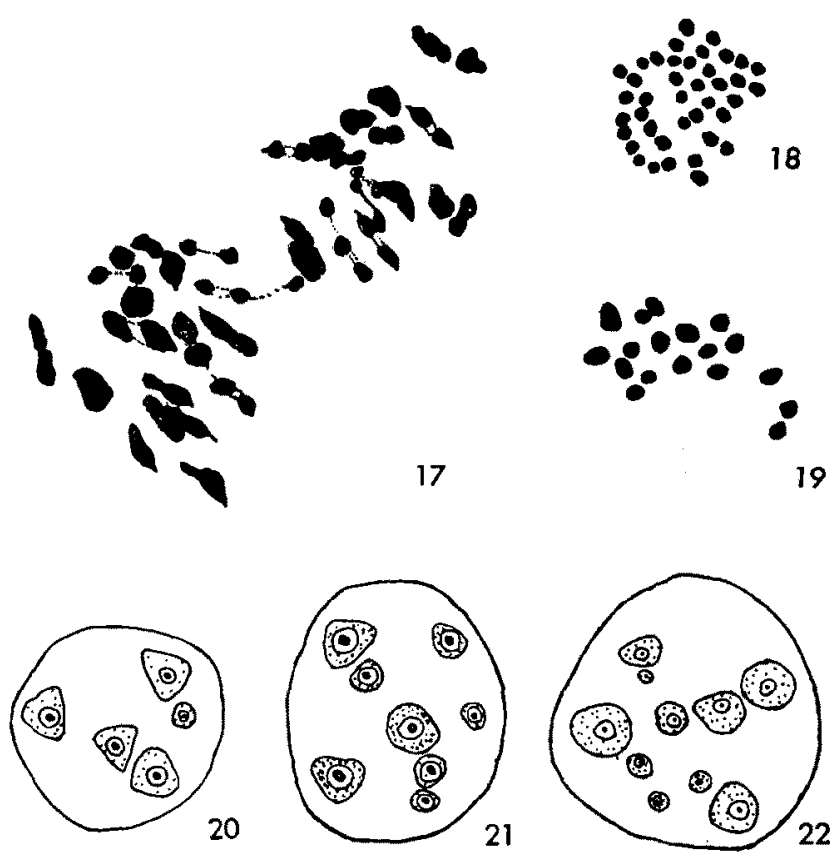

Figs. 17-22. 17, Evodia glocii. First meiotic metaphase showing associations off 33 bivalents and 2 trivalents. $n=36 . \quad \times$ 2660. 18, Ailanthus altissima. First meiotic metaphase. Pollen mother cell. $\mathrm{n}=40 . \times 760.19$, Quassia amara. First meiotic metaphase showing $\mathrm{n}=18$. Pollen mother cell. $\times 1520$. $20,21,22$, Quassia amara. Abnormal formation of micro. spores at the end of Meiosis II. $\times 760$.
E. N. America and this has presumably taken place in high Northern latitudes. These considerations suggest an ancient continuity of territory between America and Asia presumably existing during the tertiary period.

In order to determine the age of the species of Xanthoxylum, some fossil remains of the plants were examined by the writer. The following three species are preserved as fossils.

\section{1) Zanthoxylum} juglandinium was found at Oeningen in Switzerland.

2) Zanthoxylon costatum is preserved at the Isle of Wight, from the middle Oligocene period. The fossil remains of a seed and leaves of this plant have been preserved. From the perfect state of the seed, it is estimated that it has travelled only a little distance. This species is not completely identical with the living species of either Xanthoxylum or Fagara, a closely allied genus.

3) Zanthoxylon spiraceaefolium Lesq. (Schimper and Schenk, 187990) was represented in the Tertiary period in N. America. This particular species is now extinct in N. America. Presumably it was destroyed during 
the Pleistocene glaciations. The genus therefore was formerly less restricted in its distribution and occurred in Europe.

Family Simarubaceae. The family Simarubaceae is closely allied to the Rutaceae morphologically, differing mainly in the absence of oil glands and in the marked tendency to unisexuality in the flowers.

Ailanthus altissima. The chromosome count for Ailanthus altissima shows that $n=40$ (Fig. 18) and is the first recorded count for the genus. In the pollen mother cells, small meiotic irregularities are observed. In Fig. 16 a lagging chromosome at second anaphase is shown. The anthers exhibit a considerable number of degenerated or defective pollen.

Quassia amara. In the pollen mother cell of Quassia amara, 18 chromosomes are counted (Fig. 19). This is in agreement with Janaki Ammals $(1955)^{1}$ record of $2 n=36$ for the material obtained from Guiana.

Abnormal tetrad formation is observed in Quassia. Figs. 20, 21, 22, show formations of 5,8 and 10 spores in a tetrad. The disturbance in the normal meiotic behaviour may have been due to susceptibility to environmental changes. Darlington (1937) has discussed several cases of abnormality in microspore formation. He attributed the phenomenon to the variable behaviour of dividing cells in which the normal relationship of the spindles to the chromosomes have been upset by failure of pairing.

\section{Discussion}

\section{1) Chromosome size}

Though both Dictamnus and Correa are herbs, considerable difference in absolute chromosome size exists in them. Those of Dictamnus are of the size $1-1.2 \mathrm{~m}$ in the pollen mother cell. Correa growing in the hot houses in London has fairly large chromosomes $(1.5 \mathrm{~m})$. Those of Choisya are the largest chromosomes observed $(1.8 \mathrm{~m})$. It should be noted however that medium sized chromosomes are characteristic of the family Rutaceae and are observed in most of the genera so far investigated.

It is now believed that differences in absolute size of the chromosomes have nothing to do with the size of the chromonema or gene string but are related to the coiling properties of the DNA and to the amount and distribution of certain chemical substances in the chromosomes.

It is also found that external factors control to some extent differences in chromosome size. Pierce $(1937)^{2}$ in Viola records that lack of phosphorous in the nutrition of the plant causes considerable reduction in the size of the chromosomes. It has been found that species with larger chromosomes occupy cooler climates. In the Simarubaceae, Quassia growing in Bombay, has smaller chromosomes $(.85-1 \mu)$ when compared with those of Ailanthus $(1.25 \mu)$ growing in the temperate zones. However the extent to which

1 Ref. Darlington, C. D. and Wylie, A. P. (1955).

2 Ref. Stebbins, G. L. 
external factors can control absolute chromosome size in general needs further to be explored.

It is not possible to decide whether the reduction or increase in absolute chromosome size in the Rutaceae is phylogenetic, for there is no evidence on this point.

2) Chromosome numbers

There can be no doubt that the basic chromosome number in the Rutaceae is 9 , since this number has already been found recorded in several sub. families and tribes. Modification of the primitive chromosome set has been either by a stepwise increase in the basic chromosome number or by poly. ploidy. For example diploid chromosome numbers recorded in Xanthoxylum are as follows:

$\begin{array}{lll}\text { X. clava-herculis (Fagara) } & -72(8 \times) & \text { Bowden, } 1940 \\ \text { X. piperitum } & -70 . & \text { Nakajima, 1937 } \\ \text { X. americanum } & -68 . & \text { Walker, } 1942\end{array}$

My determinations are:

$\begin{array}{lll}X . \text { americanum } & -136 . & \text { Desai, } 1956 \\ X . \text { bungeii } & -32 . & \text { Desai, } 1956\end{array}$

In the present investigation, the chromosome number $2 \mathrm{n}=136$ for $X$. americanum is the highest count recorded in the whole family; also aneuploid changes have been observed for the first time in Evodia.

Some authorities consider that the relative ages of species can be to some extent estimated by comparison of their chromosome numbers. Material of Xanthoxylum obtained from the British Isles has a higher chromosome number than that determined as $2 n=68$ by Walker (1942) for the same species in America. The former material has presumably originated from the latter. The doubling of the chromosome number may have been due to ecological causes and related to irregularities observed at meiosis (Desai 1956).

Polyploids are most successful in habitats which are newly acquired. The few chromosome numbers published and those found by the Author show the present day Xanthoxyleae to be high polyploids.

3) Observations othe: than chromosome numbers

The irregularities in meiosis observed in some of the species are described earlier. Irregular tetrad formation occurs in Quassia. A tetrahedral arrange. ment of microspores in a tetrad is common to all the plants of the Rutaceae and the Simarubaceae under the present investigation. It was observed in all the plants except Skimmia that the stages of development of the mother cells were widely different in the anthers of one flower or even in the sporangia of one and the same anther. For instance, in one microsporangium the mother cells may be in the later stages of meiosis when in others of the same anther they may be yet in prophase. 


\section{Summary}

1. Chromosome numbers have been determined for the first time for 10 species belonging to 8 genera of the two families, Rutaceae and Simarubaceae.

2. The process of meiosis has been studied in detail in the pollen mother cells of these plants and the irregularities during meiosis noted.

3. Formation of univalents and trivalents is observed in Ptelea and in Evodia glocii.

4. Polyploidy is observed in Xanthoxylum and aneuploid changes in Evodia danielli.

\section{Acknowledgements}

The author wishes to express her indebtedness to Dr. M. B. E. Godward for encouragement throughout this investigation. Thanks are due to $\mathrm{Sir}$ Edward Salisbury, Director, Royal Botanic Gardens, Kew for most of the material.

\section{Literature cited}

Asa, Gray 1858-59. Observations upon the relation of the Japanese flora to that of $\mathrm{N}$ America. Mem. Amer. Acad. Sci. 6: 377-451.

Bowden, W. M. 1940. Diploidy, polyploidy and winter hardiness relationships in the flowering plants. Amer. J. Bot. 27: 357-371.

- 1945. A list of chromosome numbers in higher plants I. Acanthacae to Myrtaceae. Amer. J. Bot. 32: 81-92.

Darlington, C. D. 1937. Recent Advances in Cytology. 2nd ed. Churchill Ltd. London.

- and Wylie, A. P. 1955. Chromosome Atl s of Flowering plants. George Allen and Unwin Ltd. London.

Desai, S. R. 1956. The mechanism of apomixis in Xanthoxylum. Unpublished. (Thesis, University of London).

Nakajima, G. 1937. Cytological studies on some dioecious plants. Cytologia Fujii. Jub: Vol.: $282-293$.

Osawa, O. 1912. Cytological and experimental studies in Citrus. J. Coll. Agr. Tokyo, 4: $83-116$.

Schimper, A. F. W. and Schenck, H. 1879-90. Handbuch der Paleontologie. München and Leipzig.

Stebbins, G. L. Variation and Evolution in Plants. Columbia University Press, New York.

Smith-White, S. 1954b. Chromosome numbers in the Boroneae (Rutaceae) and their bearing on the evolutionary development of the tribe in the Australian flora. Aust. Jour Bot. 2: 287-303.

Walker, R. I. 1942. Chromosome number of Zanthoxylum Americanum. Bot. Gaz. 103: 625-626. 